\title{
RAW WATER USE CHARGE REDUCTION FOR THE RURAL SECTOR IN THE PCJ WATERSHED ${ }^{1}$
}

\author{
ROGÉRIO T. DA SILVA², MARCOS V. FOLEGATTI ${ }^{3}$
}

\begin{abstract}
The deficient environmental preservation on agricultural properties has reflected in great soil losses for erosion and the high rate of sedimentation. Therefore, this work brings the application of software to demonstrate that planters can get benefits by the conservationist practices. The benefits will be obtained from the environment aspect (erosion and sedimentation control), as well as economical aspect (financial incentives). A proposal has been created by the Technical Chamber of Rural Water Use and Conservation (CT-Rural) to estimate the reduction in raw water use charge for the rural water users of the PCJ Watershed - this reduction is being possible since January 2007, at the PCJ Committee. The software develops a simple relationship, so that if the rural conservationist action goes more efficient, such as if the conserved rural area goes larger, then the reduction value will bring better benefits for the rural water users. Within the purposes of this study, there is the idealization of mechanisms that may support specific management matters related to the water users of federal rivers from the rural sector of PCJ Watershed.
\end{abstract}

KEYWORDS: software, conservation practice, watershed committee, raw water use charge.

\section{REDUÇÃO DA COBRANÇA PELO USO DA ÁGUA PARA O SETOR RURAL NAS BACIAS PCJ}

RESUMO: Considerando as implicações da insuficiência de preservação ambiental em propriedades agrícolas refletidas em grandes perdas de solos erodidos e sedimentação de mananciais, buscou-se, neste trabalho, demonstrar que, com a utilização de práticas conservacionistas, agricultores poderão ser beneficiados tanto no aspecto ambiental, pelo abatimento da erosão em suas propriedades, quanto no aspecto econômico, ou seja, por meio de proposta inicialmente deliberada pela Câmara Técnica de Uso e Conservação da Água no Meio Rural (CT-Rural) dos Comitês PCJ para o cálculo da redução da cobrança pelo uso da água que incide sobre o setor rural - o que será permitido pelos Comitês PCJ a partir de janeiro de 2007. Dessa forma, este trabalho traz como objetivo principal o desenvolvimento de programa computacional cujo método de cálculo apresenta uma simples relação, de forma que, quanto mais eficiente for a prática conservacionista, bem como quanto maior a área conservada, maior deverá ser o percentual de redução da cobrança que incide sobre os usuários do setor rural que captam as águas dos rios federais das Bacias PCJ. Portanto, tal programa apresenta-se como importante ferramenta de auxílio para questões específicas de gestão dos recursos hídricos relacionadas aos usuários de água do setor rural das Bacias PCJ.

PALAVRAS-CHAVE: programa computacional, prática conservacionista, comitê de bacias hidrográficas, cobrança pelo uso da água.

\section{INTRODUCTION}

The raw water use charge from the PCJ Watershed Committee (Piracicaba, Capivari and Jundiaí Rivers) started on January 1, 2006. Within all water users of federal domain rivers (Watershed PCJ), there are the users of the rural sector include irrigation agriculture, aquiculture and animal raising (PCJ Federal, 2003). The development of the water resources management in the

\footnotetext{
${ }^{1}$ Trabalho financiado pela Fundação de Amparo à Pesquisa do Estado de São Paulo.

${ }^{2}$ Pós-Doutorando, ESALQ/USP, Av. Pádua Dias 11, Piracicaba - SP, Fone: (0XX19) 3429-4217, rtsilva@ esalq.usp.br

${ }^{3}$ Eng $^{\mathrm{o}}$ Agr ${ }^{\mathrm{o}}$, Prof. Titular, ESALQ/USP, Av. Pádua Dias 11, Piracicaba - SP, mvfolega@esalq.usp.br

Recebido pelo Conselho Editorial em: 10-12-2007

Aprovado pelo Conselho Editorial em: 9-8-2009
}

Eng. Agríc., Jaboticabal, v.29, n.3, p.492-500, jul./set. 2009 
Piracicaba, Capivari and Jundiaí Rivers Watershed Committees (PCJ Committees) happens with the works of the PCJ Executive Secretariat (ES), Accompanying Groups (AGs), Technical Groups (TGs), and also eleven Technical Chambers (TCs) with deliberative functions.

The Technical Chamber of Rural Water Use and Conservation (CT-Rural) has its own responsibilities, such as the elaboration of proposals about directions and joint actions. The CTRural has the function of promoting the integration and the optimization of procedures among the institutions that actuate within the rural area, aiming the preservation, conservation and water resources sustainable use (CT-RURAL, 2005).

Aiming to meet the Resolution Nr. 52 from the National Council on Water Resources (CNRH, 2005) the CT-Rural deliberated a proposal to estimate the reduction in raw water use charge from federal domain rivers for the rural water users (CT-RURAL, 2006) - according to the possibility for the rural users to get a reduction in the value charged from January 2007.

Such a resolution creates a distinct mechanism of payment for this sector with the purpose of encouraging investments with the planter's own resources by conservationist practices for water quality and quantity improvements, such as the fluvial regimen to result in environmental sustainability of the PCJ Watershed. The PCJ Watershed Plan (CBH-PCJ and FEDERAL PCJ, 2006) appoint the CT-Rural to fix these practices. The conservationist practices should include application of good actions of use and conservation of water on rural properties where the uses of water resources take place.

\section{MATERIAL AND METHODS}

Initially, starting from the database of the PCJ watershed irrigation mapping (CADIR, 2004), the erosion control conditions and the irrigation handling situations were identified. However, this database is in elaboration phase and only two subwatersheds were mapped with 1,259 irrigation areas located in the Atibaia River Subwatershed and Jaguari River Subwatershed (PCJ Rivers Watershed - Figure 1). The objective of this initial identification is to make clear the dimension of the environmental problems and, consequently, to emphasize the importance of the incentives for conservationist farmers.

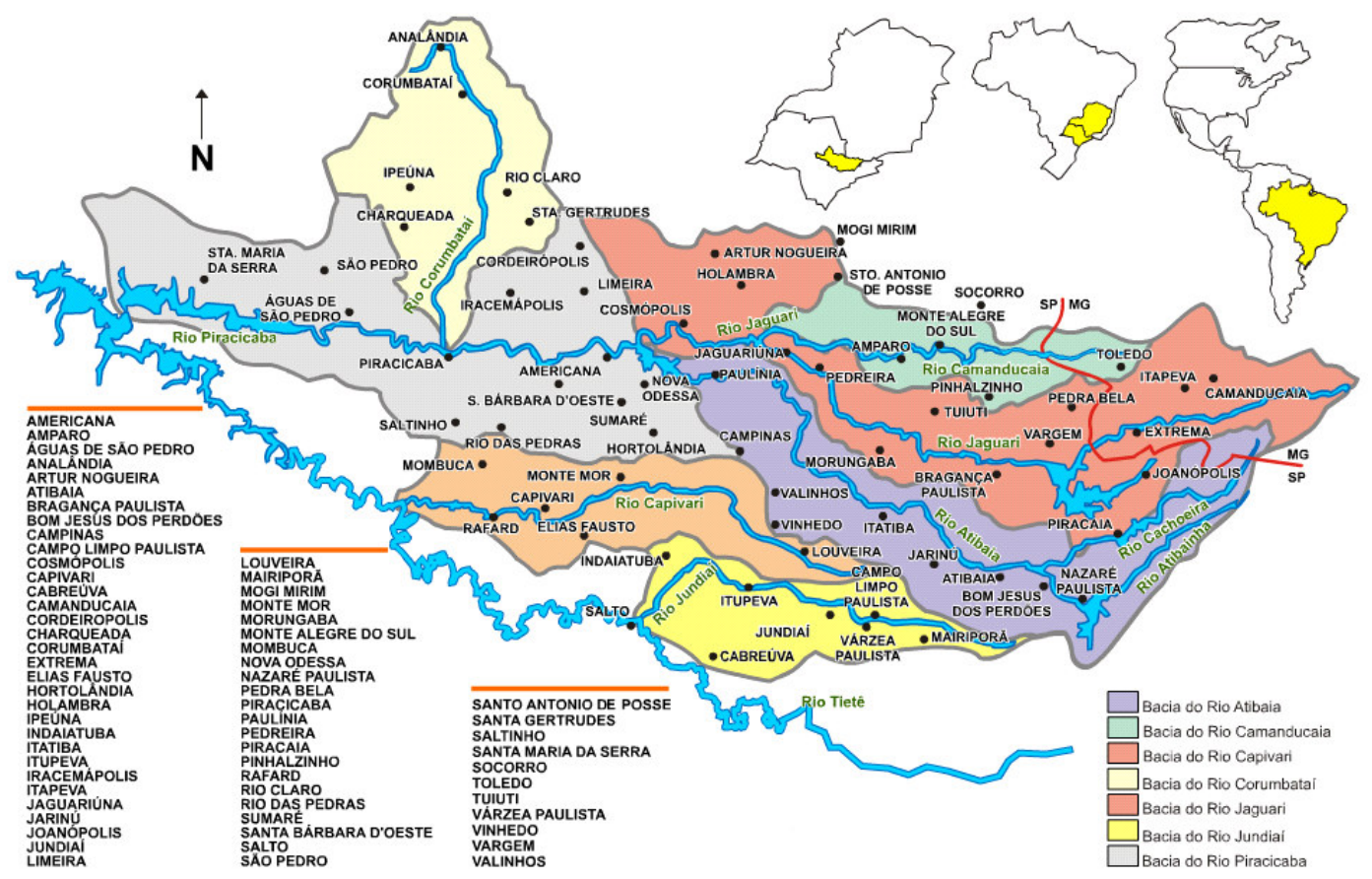

FIGURE 1. Piracicaba, Capivari and Jundiaí (PCJ) Rivers Watershed. 
In the ambit of the CT-Rural, the initial proposal for the determination of the reduction in raw water use charge has been supported by a software development in Delphi program language.

The software uses the equation applied by the Program called "Water Production" (ANA, 2003) to estimate the percentage of the erosion reduction, that is:

$$
\mathrm{PAE}=100\left(1-\frac{\mathrm{Z}_{1}}{\mathrm{Z}_{0}}\right)
$$

where,

PAE - erosion reduction percentage, \%; and,

$\mathrm{Z}$ - relation between the factor of usage and soil handling and the factor of conservation practices from the Universal Soil Loss Equation - USLE (WISCHMEIER \& SMITH, 1978) non-dimensional.

According to CHAVES (2004), the percentage of erosion reduction (PAE) can be estimated by table $\mathrm{Z}_{0}$ and $\mathrm{Z}_{1}$ parameters for the use, handling and practices of the conventional situations (Table 1) and conservation (Table 2) in a process where it is much simpler and economical than a monitoring on the field.

Under the hypothesis that the larger the preserved area and the more efficient the preservation practice is, the bigger the reduction value is, which is given by the following equation:

$$
\mathrm{PAC}_{\mathrm{T}}=\left(\frac{\mathrm{Gc}}{\mathrm{A}_{\mathrm{T}}}\right) \mathrm{PAE}
$$

where,

$\mathrm{PAC}_{\mathrm{T}}$ - total of reduction in raw water use charge for rural sector, \%;

Gc - area of preserved soil, ha; and,

$\mathrm{A}_{\mathrm{T}}$ - total area of the rural property with ability agricultural activities or good for reforestation, ha.

Considering that a planter may adopt several conservation practices in different areas of his rural property, the software will give the sum of values of $Z_{0}$ (Table 1) and of values of $Z_{1}$ (Table 2) corresponding to the " $\mathrm{n}$ " practices adopted. By means of this analysis and due to the replacement of values, this work brings the following equation:

$$
\text { PAC }_{T}=100\left(\frac{\sum_{n=11}^{29} G c}{A_{T}}\right)\left(1-\frac{\sum_{n=11}^{29} z_{1 n}}{\sum_{n=1}^{10} z_{0_{n}}}\right)
$$

where,

$$
\begin{aligned}
& 100\left(\frac{\sum_{\mathrm{n}=11}^{29} \mathrm{Gc}}{\mathrm{A}_{\mathrm{T}}}\right)=\mathrm{AC}=\text { Conserved area, } \% ; \text { and, } \\
& \left(1-\frac{\sum_{\mathrm{n}=11}^{29} \mathrm{z}_{1 \mathrm{n}}}{\sum_{\mathrm{n}=1}^{10} \mathrm{z}_{0_{\mathrm{n}}}}\right)=f c=\text { Conservation factor, non-dimensional. }
\end{aligned}
$$


TABLE 1. Values of $Z_{0}$ for the conventional practices.

\begin{tabular}{ccc}
\hline $\mathrm{n}$ & Conventional Practices & $\mathrm{Z}_{0}$ \\
\hline 1 & Grains & 0.25 \\
2 & Cotton & 0.62 \\
3 & Manioc & 0.62 \\
4 & Sugar cane & 0.10 \\
5 & Potato & 0.75 \\
6 & Coffee & 0.37 \\
7 & Vegetables & 0.50 \\
8 & Degraded pasture & 0.25 \\
9 & Degraded thicket & 0.15 \\
10 & Bare soil surface & 1.00 \\
\hline
\end{tabular}

TABLE 2. Values of $Z_{1}$ for the conservationist practices.

\begin{tabular}{ccc}
\hline $\mathrm{n}$ & Conservationist Practices & $\mathrm{Z}_{1}$ \\
\hline 11 & Grains - crop rotation & 0.20 \\
12 & Grains - contour cultivation & 0.13 \\
13 & Grains - crop rotation and contour cultivation & 0.10 \\
14 & Grains - strip cropping & 0.08 \\
15 & Grains - spreader strip & 0.05 \\
16 & Grains - direct drilling & 0.03 \\
17 & Cotton \& Manioc - crop rotation & 0.40 \\
18 & Cotton \& Manioc - contour cultivation & 0.31 \\
19 & Cotton \& Manioc - direct drilling & 0.04 \\
20 & Sugar Cane - contour cultivation & 0.05 \\
21 & Sugar Cane - strip cropping & 0.03 \\
22 & Potato - contour cultivation & 0.38 \\
23 & Potato - strip cropping & 0.22 \\
24 & Coffee - contour cultivation & 0.19 \\
25 & Coffee - strip cropping & 0.11 \\
26 & Vegetables - contour cultivation & 0.25 \\
27 & Recovered pasture & 0.12 \\
28 & Crop rotation between pasture and grains & 0.10 \\
29 & Dense reforestation & 0.01 \\
\hline
\end{tabular}

The methodology of this study includes a hypothetical example of application of the developed software and, with the database of the PCJ watershed irrigation mapping (CADIR, 2004) the results of the raw water use charge reduction will be demonstrated. These results refer to the farmers that adopt contour cultivation on their properties as soil erosion control practice for the cultivation of vegetables with location in the Atibaia and Jaguari Rivers Subwatershed cities.

\section{RESULTS AND DISCUSSIONS}

Based on the PCJ watershed irrigation mapping (CADIR, 2004), the information in this study about soil erosion control and irrigation handling was gathered in the Tables 3 and 4, respectively. 
TABLE 3. Amount of farmers and the used erosion control condition (cities of the Atibaia River Subwatershed and Jaguari River Subwatershed).

\begin{tabular}{|c|c|c|c|c|c|c|c|}
\hline \multirow{2}{*}{ City } & \multicolumn{6}{|c|}{ Used Erosion Control Level - Conditions ${ }^{(1)}$} & \multirow{2}{*}{ Total } \\
\hline & A & $\mathrm{B}$ & $\mathrm{C}$ & $\mathrm{D}$ & $\mathrm{E}$ & $\mathrm{F}$ & \\
\hline Amparo & & & 2 & & & 124 & 126 \\
\hline Atibaia & 2 & & 3 & 3 & 4 & 378 & 390 \\
\hline B.J.Perdões & & & & & & 33 & 33 \\
\hline Bragança Paulista & & & & & & 120 & 120 \\
\hline Itatiba & & & & & & 82 & 82 \\
\hline Jarinu & & & 17 & 2 & 4 & 109 & 132 \\
\hline Monte Alegre do Sul & & & 1 & & & 71 & 72 \\
\hline Morungaba & & & & & & 20 & 20 \\
\hline Narazé Paulista & & & & & & 44 & 44 \\
\hline Pedra Bela & & & 8 & & 1 & 42 & 51 \\
\hline Pinhalzinho & & 1 & & & & 36 & 37 \\
\hline Piracaia & & & & & & 23 & 23 \\
\hline Socorro & & & & & & 45 & 45 \\
\hline Tuiuti & & & 1 & & 5 & 37 & 43 \\
\hline Valinhos & & & & & & 41 & 41 \\
\hline Total of farmers & 2 & 1 & 32 & 5 & 14 & 1,205 & 1,259 \\
\hline Total (\%) & 0.16 & 0.08 & 2.54 & 0.40 & 1.11 & 95.71 & 100 \\
\hline
\end{tabular}

${ }^{(1)} \mathbf{A}$ - direct drilling; $\mathbf{B}$ - contour terrace; $\mathbf{C}$ - contour cultivation; D - strip cropping; $\mathbf{E}$ - plane area; $\mathbf{F}$ - without soil erosion control.

TABLE 4. Amount of farmers and the used irrigation handling condition (cities of the Atibaia River Subwatershed and Jaguari River Subwatershed).

\begin{tabular}{|c|c|c|c|c|c|c|}
\hline \multirow{2}{*}{ City } & \multicolumn{5}{|c|}{ Irrigation Handling - Conditions ${ }^{(1)}$} & \multirow{2}{*}{ Total } \\
\hline & A & $\mathrm{B}$ & $\mathrm{C}$ & $\mathrm{D}$ & $\mathrm{E}$ & \\
\hline Amparo & & & & & 126 & 126 \\
\hline Atibaia & & & & & 390 & 390 \\
\hline B.J.Perdões & & & & & 33 & 33 \\
\hline Bragança Paulista & & & & & 120 & 120 \\
\hline Itatiba & & & & & 82 & 82 \\
\hline Jarinu & & 1 & & & 131 & 132 \\
\hline M. Alegre do Sul & & & & & 72 & 72 \\
\hline Morungaba & & & & & 20 & 20 \\
\hline Narazé Paulista & & & & & 44 & 44 \\
\hline Pedra Bela & & & & & 51 & 51 \\
\hline Pinhalzinho & & & & & 37 & 37 \\
\hline Piracaia & & & & & 23 & 23 \\
\hline Socorro & & & & & 45 & 45 \\
\hline Tuiuti & & & 2 & & 41 & 43 \\
\hline Valinhos & & & & & 41 & 41 \\
\hline Total of farmers & 0 & 1 & 2 & 0 & 1,256 & 1,259 \\
\hline Total (\%) & 0.00 & 0.08 & 0.16 & 0.00 & 99.76 & 100 \\
\hline
\end{tabular}

${ }^{(\mathrm{I})} \mathbf{A}$ - evaporation tank use; $\mathbf{B}$ - stress meter use; C - pluviometer use; D - weather station database use; $\mathbf{E}$ - visual control.

The Table 3 and the Table 4 reveal alarming information related to the environmental aspect for all cities of both analyzed subwatersheds. For the involved cities, the Table 3 shows that 1,205 farmers do not use any conservationist practice of soil erosion control on their rural properties (95,71\% of 1,259 farmers). This situation becomes more alarming when observed that the irrigation 
handling is marked by the empiricism, that is, 1,256 farmers $(99,76 \%$ of 1,259 farmers) control the applications of water exclusively in a visual way, without technical criteria.

In this aspect, BERNARDO et al. (2006) describes that the irrigation practices are usually based on inherited habits or individual convenience, instead of correct analyses for the present conditions.

Many farmers have been demonstrating environmental consciousness, but they have small disposition of investments for conservationist practices and recovery of forest areas, due to the fragile financial situation. The development of new mechanisms to motivate the rural sector becomes evident and, in this aspect, these mechanisms should promote the adoption of water and soil conservation practices. Therefore, this work can bring great contribution for PCJ Watersheds through the raw water use charge reduction proposal.

The software interface (Figure 2) shows the raw water use charge reduction equation decomposed in two terms. The first term "AC" represents the conserved area percentage on the rural property and, the second term " $f c$ " represents the conservation factor, non-dimensional, related to the planter's environmental actions.

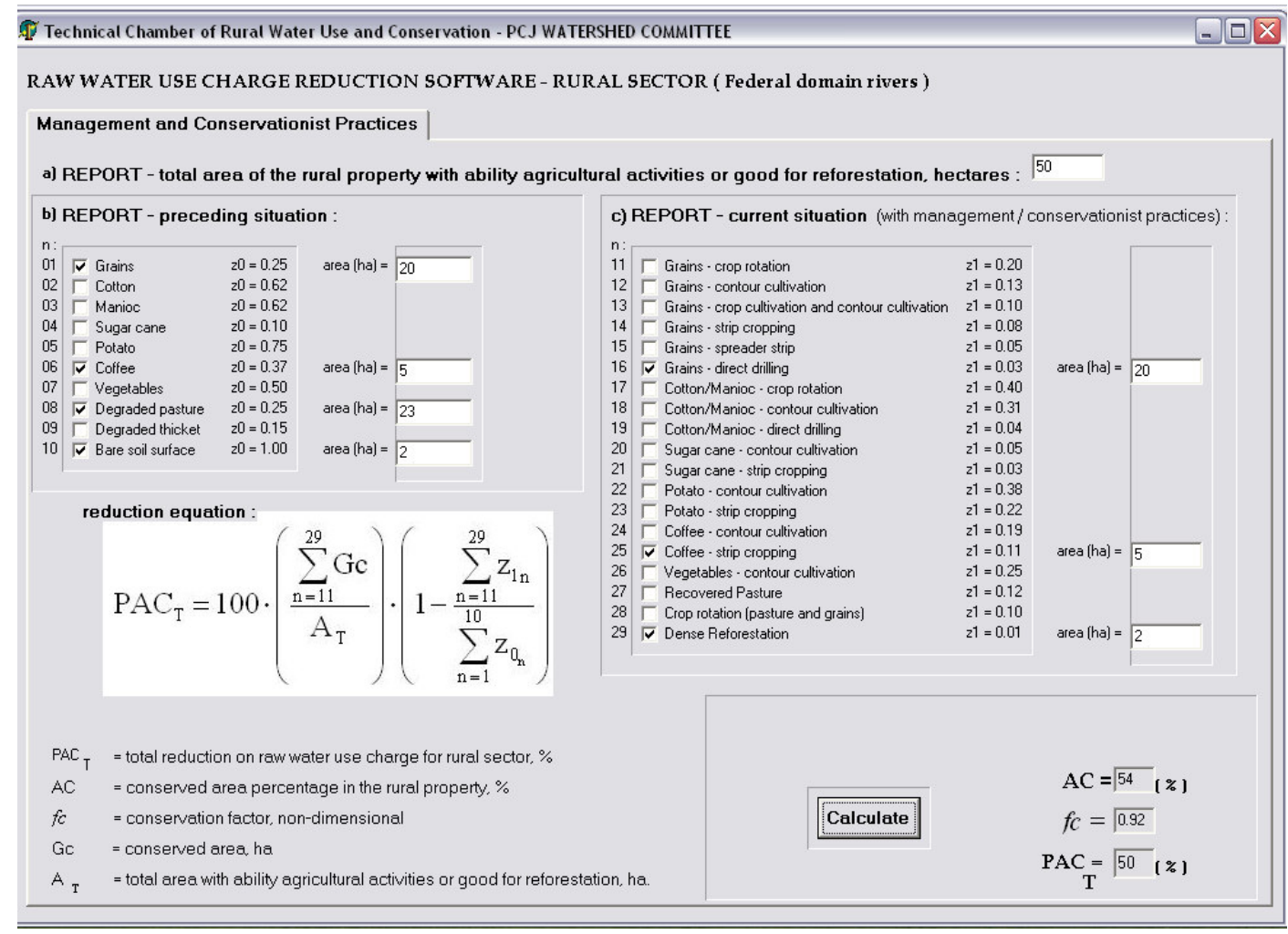

FIGURE 2. Software interface.

The Figure 2 shows an example for raw water use charge reduction calculation. The example brings hypothetical situation of a rural property (50 hectares total area) with agricultural ability or reforestation capacity. This total area is fractioned in 20 hectares area with grain cultivation $\left(Z_{0}=0.25\right)$ and 5 hectares area with coffee cultivation $\left(Z_{0}=0.37\right)$ without conservationist practices, in addition to 23 hectares area with degraded pasture $\left(Z_{0}=0.25\right)$ and 2 hectares area without cover crop and high erosion susceptibility $\left(Z_{0}=1.00\right)$. However, the hypothetical planter's management practices can be shown: a) implementation of direct drilling technique for the grain cultivation $\left(Z_{1}=0.03\right)$ in those 20 hectares area; b) strip cropping construction for the coffee cultivation 
$\left(Z_{1}=0.11\right)$ in those 5 hectares area; $\left.c\right)$ adequate reforestation planning for the erosion risk area $\left(Z_{1}=0.01\right)$ in those 2 hectares area.

The results of this example point to the rural area conservation percentage "AC" that is equal $54 \%$ in relation to the agricultural ability or reforestation capacity total area. The conservationist factor that is equal 0.92 and, finally, the raw water use charge total reduction " $\mathrm{PAC}_{\mathrm{T}}$ " that is equal $50 \%$. Regarding this conjecture, the " $f c$ " value, it was relatively big. This fact demonstrates that the conservationist practices will produce efficient environmental results. However, the "PAC $\mathrm{T}_{\mathrm{T}}$ " value could increase if the 23 hectares area with degraded pasture had also been receiving environmental adaptation, what did not actually happen for presented hypothesis.

The information of PCJ watershed irrigation mapping (CADIR, 2004) demonstrate that the irrigated vegetables prevail on the other cultures found in the Atibaia and Jaguari Rivers Watershed cities.

Then, the information of the Table 3 shows that only 32 farmers use contour cultivation to control the soil erosion. Through the development of the eq. (3) terms, the values of AC (conserved area) are obtained and demonstrated in the tables 5; 6 and 7 for the 32 farmers, as well as the " $f c$ " value (conservationist factor) considering the adoption of contour cultivation practice adopted by these farmers:

$$
f c=\left(1-\frac{\sum_{\mathrm{n}=11}^{29} \mathrm{z}_{1 \mathrm{n}}}{\sum_{\mathrm{n}=1}^{10} \mathrm{z}_{0_{\mathrm{n}}}}\right)=\left(1-\frac{0.25}{0.50}\right)=0.5
$$

The construction of the tables involving all cities of the Atibaia and Jaguari Rivers Subwatersheds where the farmers use contour cultivation practice are demonstrated in the sequence:

TABLE 5. Raw water use charge reduction for the farmers that use contour cultivation practice $(f c=0,5)$ - they are located in the following cities: Amparo, Atibaia, Monte Alegre do Sul e Tuiuti.

\begin{tabular}{lccccrr}
\hline City & $\begin{array}{c}\text { Farmer } \\
\text { (quantity) }\end{array}$ & $\begin{array}{c}\text { Total Area } \\
(\text { ha) }\end{array}$ & $\begin{array}{c}\text { Irrigated Area } \\
(\text { ha) }\end{array}$ & $\begin{array}{r}\text { AC } \\
(\%)\end{array}$ & $\begin{array}{c}f c \\
-\end{array}$ & $\begin{array}{c}\text { PAC } \\
(\%)\end{array}$ \\
\hline Amparo & 1 & 4.0 & 0.8 & 20.0 & 0.5 & 10.0 \\
Amparo & 2 & 13.3 & 7.3 & 54.9 & 0.5 & 27.4 \\
Atibaia & 3 & 9.0 & 0.5 & 5.6 & 0.5 & 2.8 \\
Atibaia & 4 & 3.5 & 1.0 & 28.6 & 0.5 & 14.3 \\
Atibaia & 5 & 12.0 & 5.0 & 41.7 & 0.5 & 20.8 \\
Monte Alegre do Sul & 6 & 29.7 & 4.0 & 13.5 & 0.5 & 6.7 \\
Tuiuti & 7 & 21.8 & 21.8 & 100.0 & 0.5 & 50.0 \\
\hline
\end{tabular}

TABLE 6. Raw water use charge reduction for the farmers that use contour cultivation practice $(f c=0,5)$ - they are located in the Pedra Bela city.

\begin{tabular}{lcccccr}
\hline City & $\begin{array}{c}\text { Farmer } \\
\text { (quantity) }\end{array}$ & $\begin{array}{c}\text { Total Area } \\
\text { (ha) }\end{array}$ & $\begin{array}{c}\text { Irrigated Area } \\
(\text { ha) }\end{array}$ & $\begin{array}{c}\text { AC } \\
(\%)\end{array}$ & $\begin{array}{r}f_{c} \\
-\end{array}$ & $\begin{array}{r}\text { PAC } \\
(\%)\end{array}$ \\
\hline \multirow{4}{*}{ Pedra Bela } & 8 & 3.0 & 3.0 & 100.0 & 0.5 & 50.0 \\
& 9 & 2.4 & 2.4 & 100.0 & 0.5 & 50.0 \\
& 10 & 48.4 & 12.0 & 24.8 & 0.5 & 12.4 \\
& 11 & 28.0 & 8.3 & 29.6 & 0.5 & 14.8 \\
& 12 & 106.0 & 8.5 & 8.0 & 0.5 & 4.0 \\
& 13 & 2.4 & 1.5 & 62.5 & 0.5 & 31.3 \\
& 14 & 3.5 & 0.5 & 14.3 & 0.5 & 7.1 \\
& 15 & 9.5 & 9.5 & 100.0 & 0.5 & 50.0 \\
\hline
\end{tabular}


TABLE 7. Raw water use charge reduction for the farmers that use contour cultivation practice $(f c=0,5)$ - they are located in the Jarinu city.

\begin{tabular}{ccccccr}
\hline City & $\begin{array}{c}\text { Farmer } \\
\text { (quantity) }\end{array}$ & $\begin{array}{c}\text { Total Area } \\
\text { (ha) }\end{array}$ & $\begin{array}{c}\text { Irrigated Area } \\
\text { (ha) }\end{array}$ & $\begin{array}{c}\text { AC } \\
(\%)\end{array}$ & $\begin{array}{r}f c \\
-\end{array}$ & $\begin{array}{r}\text { PAC } \\
(\%)\end{array}$ \\
\hline \multirow{6}{*}{16} & 24.2 & 9.0 & 37.2 & 0.5 & 18.6 \\
& 17 & 14.5 & 12.0 & 82.8 & 0.5 & 41.4 \\
18 & 10.9 & 5.0 & 45.9 & 0.5 & 22.9 \\
19 & 36.3 & 5.0 & 13.8 & 0.5 & 6.9 \\
& 20 & 12.1 & 6.0 & 49.6 & 0.5 & 24.8 \\
& 21 & 7.2 & 2.4 & 33.3 & 0.5 & 16.7 \\
& 22 & 2.4 & 1.0 & 41.7 & 0.5 & 20.8 \\
& 23 & 6.0 & 4.0 & 66.7 & 0.5 & 33.3 \\
& 24 & 14.5 & 3.0 & 20.7 & 0.5 & 10.3 \\
& 25 & 26.6 & 3.5 & 13.2 & 0.5 & 6.6 \\
& 26 & 13.4 & 8.0 & 59.7 & 0.5 & 29.9 \\
& 27 & 14.5 & 3.6 & 24.8 & 0.5 & 12.4 \\
& 28 & 60.0 & 1.5 & 2.5 & 0.5 & 1.3 \\
& 29 & 2.0 & 2.0 & 100.0 & 0.5 & 50.0 \\
& 30 & 2.4 & 0.7 & 29.2 & 0.5 & 14.6 \\
& 31 & 10.0 & 1.5 & 15.0 & 0.5 & 7.5 \\
& 32 & 2.4 & 1.0 & 41.7 & 0.5 & 20.8 \\
\hline
\end{tabular}

Therefore, by this software development that has easy application, the raw water use charge reduction is estimated in function of adequate water use and conservation practices on the rural properties, as established by Resolution $\mathrm{N}^{\circ} 52$ of the National Council of Water Resources (CNRH/Brazil). The use of this software by PCJ Committee can demonstrate the environmental and economics benefits for conservationist planters, which provide environmental sustainability on rural properties.

Emphasis is placed on the discussion of the CT-Rural to upgrade the raw water use charge reduction proposal. The improvement of rural ways, utilization of more efficient irrigation methods and adhesion of planters to state conservation programs may represent essential elements for the idealization of improved mechanisms and, consequently, reformulation of the software presented, offering benefits to the rural sector in an even more efficient manner.

\section{CONCLUSIONS}

The software developed in this work can help the PCJ Watersheds management. With the soil and water conservation practices, the farmers can receive reductions in the water's tariff, proportional to the generated environmental benefits.

\section{ACKNOWLEDGEMENTS}

We would like to thank The State of São Paulo Research Foundation (FAPESP) for granting the financial support for this research.

\section{REFERENCES}

ANA. AGÊNCIA NACIONAL DE ÁGUAS. Manual Operativo do Programa "Produtor de Água”. Brasília, 2003. 65 p.

BERNARDO, S.; SOARES, A.A.; MANTOVANI, E.C. Manual de irrigação. 8.ed. Viçosa - MG: UFV, 2006. $625 \mathrm{p}$.

CADIR. CADASTRO DE IRRIGANTES DAS BACIAS HIDROGRÁFICAS DOS RIOS PIRACICABA, CAPIVARI E JUNDIAÍ. Primeira etapa. Piracicaba: DAEE, 2004. 1 CD-ROM. 
CBH-PCJ/PCJ FEDERAL. COMITÊS DAS BACIAS HIDROGRÁFICAS DOS RIOS

PIRACICABA, CAPIVARI E JUNDIAÍ. Plano de Bacia Hidrográfica 2004-2007. Relatório final: diagnóstico e prognóstico, jan. 2006. Disponível em:

$<$ http://www.comitepcj.sp.gov.br/download/PB/PB0407_Relatorio-Completo.pdf.> Acesso em: 20 out. 2007.

CHAVES, H.M.L. Quantificação dos benefícios ambientais e compensações financeiras do Programa do Produtor de Água: Aplicação. Revista Brasileira de Recursos Hídricos, Porto Alegre, v.9, n.3, p.15-21, 2004.

CNRH. CONSELHO NACIONAL DE RECURSOS HÍDRICOS DO MINISTÉRIO DO MEIO AMBIENTE. Resolução n.52, Anexo I, Artigo 12. Diário Oficial da União, 30 nov. 2005.

CT-RURAL. CÂMARA TÉCNICA DE USO E CONSERVAÇÃO DA ÁGUA NO MEIO RURAL DOS COMITÊS PCJ. Atribuições e Composição, março, 2005. Disponível em:

<http://www.comitepcj.sp.gov.br/comitespcj.htm>. Acesso em: 18 set. 2007.

CT-RURAL. CÂMARA TÉCNICA DE USO E CONSERVAÇÃO DA ÁGUA NO MEIO RURAL DOS COMITÊS PCJ. In: Reunião CT-Rural, 14., 10 nov. 2006. Disponível em:

$<$ http://www.comitepcj.sp.gov.br/download/CT-Rural_Ata_14_Ord_10-11-06.pdf>. Acesso em: 12 set. 2007.

PCJ FEDERAL. Regimento Interno do Comitê "PCJ Federal". Artigo 5, inciso III, jan, 2003.

Disponível em: <http://www.comitepcj.sp.gov.br/comitespcj.htm>. Acesso em: 21 set. 2007.

WISCHMEIER, W.H.; SMITH, D.D. Predicting rainfall erosion losses: A guide for conservation planning. Washington, 1978. 57 p. (USDA Handbook, 537) 